\title{
PENERAPAN MODEL STUDENT TEAMS ACHIEVEMENT DIVISION BERBASIS ANTI KORUPSI UNTUK MENINGKATKAN KEAKTIFAN \\ DAN HASIL BELAJAR DALAM PEMBELAJARAN PPKn KELAS X MAN WONOKROMO
}

\author{
Oleh : \\ Rahmawati \\ Universitas Cokroaminoto Yogyakarta
}

\begin{abstract}
Abstrak
Kurang berhasilnya tujuan pembelajaran PPKn salah satunya adalah penerapan model pembelajaran oleh guru yang kurang inovatif. Selain itu penerapan nilai anti korupsi juga belum maksimal. Terkait hal tersebut, peneliti tertarik untuk meneliti tentang penerapan model student teams achievement division berbasis anti korupsi dalam pembelajaran PPKn. Tujuan dari penelitian ini adalah untuk mengetahui sejauh mana guru PPKn di MAN Wonokromo dalam menerapkan pembelajaran PPKn yang diintegrasikan dengan nilai anti korupsi, untuk mengetahui penerapan model student teams achievement division berbasis anti korupsi untuk meningkatkan keaktifan dan hasil belajar dalam pembelajaran PPKn kelas X MIA 2 tahun pelajaran 2014/2015, dan untuk mengetahui persentase keberhasilan penerapan model student teams achievement division berbasis anti korupsi untuk meningkatkan keaktifan dan hasil belajar dalam pembelajaran PPKn kelas X MIA 2. Jenis penelitian ini menggunakan Penelitian Tindakan Kelas (PTK) yang dilaksanakan dengan bekerja sama dengan guru mata pelajaran PPKn. Subjek dalam penelitian ini adalah peserta didik kelas X MIA 2. MAN Wonokromo yang berjumlah 32 peserta didik. Penelitian dilaksanakan dalam dua siklus, setiap siklus terdiri dari satu pertemuan. Instrument yang digunakan dalam penelitian ini adalah RPP, bahan ajar meliputi materi dan soal analisis kasus, lembar observasi keaktifan dan tes tertulis. Hasil penelitian menunjukkan bahwa guru PPKn hanya menerapkan nilai anti korupsi berupa nilai jujur dan percaya diri saat pembelajaran, persentase keaktifan kelas pada siklus 1 sebesar $86.25 \%$ dan siklus 2 sebesar $91.75 \%$. Untuk hasil belajar mengalami peningkatan, dari tes awal sebesar 69 menjadi 83.3 pada siklus 1 dan 87.24 pada siklus 2. Persentase ketuntasan juga meningkat. Pada pra penelitian persentase ketuntasan sebesar $45 \%$, siklus 1 sebesar $91.6 \%$ dan siklus 2 sebesar 100\%. Dari hasil penelitian diperoleh kesimpulan bahwa penerapan model student teams achievement division berbasis anti korupsi dapat meningkatkan keaktifan dan hasil belajar dalam pembelajaran PPKn. Penerapan nilai pendidikan anti korupsi yang diterapkan oleh peneliti dikelas X MIA 2 dalam pembelajaran PPKn yaitu nilai jujur, disiplin, tanggung jawab dan peduli.
\end{abstract}

Kata kunci: Model STAD, Berbasis Anti Korupsi, Peningkatan Keaktifan dan Hasil Belajar PPKn, Peserta Didik. 


\section{Pendahuluan}

Berdasarkan UU 20 tahun 2003 pasal, dapat diketahui bahwa fungsi dan tujuan pendidikan nasional mengedepankan nilai-nilai karakter, religius, ilmu pengetahuan dan moral bangsa. Perlu dispesifikan lagi fungsi dan tujuan pendidikan nasional kedalam setiap mata pelajaran agar terwujud fungsi dan tujuan pendidikan. Salah satunya dalam mata pelajaran PPKn. Mata pelajaran ini merupakan salah satu mata pelajaran yang sangat relevan untuk membentuk nilainilai karakter, religius, ilmu pengetahuan dan moral bangsa. Penerapan pembelajaran PPKn yang professional dan kompeten akan mewujudkan peserta didik yang berkualitas baik dalam disiplin sosial, etos kerja, dalam produktivitas kerja, kemampuan intelektual, tanggung jawab kemasyarakatan, kebangsaan, kemanusiaan, bermoral, berkarakter dan berkepribadian. Namun penerapan pembelajaran PPKn belum terlaksana secara profesional. Hal itu terbukti pelajar atau lulusan-lulusan pendidikan yang belum bisa menerapkan atau mengimplementasikan tujuan PPKn. Salah satunya yang berkaitan tentang karakter dan anti korupsi. Masih banyak pelajar dan lulusan-lulusan pendidikan melakukan kejahatan terutama korupsi

Penerapan pembelajaran PPKn harus profesional agar dapat mengatasi permasalahan tersebut. Proses pembelajaran PPKn harus dikolaborasikan langsung dengan nilai-nilai anti korupsi. Selain itu, model pembelajaran PPKn harus inovatif. Sampai saat ini, masih banyak guru PPKn yang belum mampu menerapkan model pembelajaran yang inovatif dengan mengkolaborasikan nilai-nilai anti korupsi. Kamil (2008) mengemukakan bahwa :

Masalah utama dalam pembelajaran Pendidikan Kewarganegaraan ialah penggunaan metode dan model pembelajaran dalam penyampaian materi pelajaran secara tepat, yang memenuhi muatan tatanan nilai, agar dapat di internalisasikan pada diri peserta didik serta mengimplementasikan hakekat pendidikan nilai dalam kehidupan sehari-hari belum sesuai dengan yang diinginkan.

Hasil wawancara peneliti dengan guru $\mathrm{PPKn}^{1}$ terdapat permasalahan dalam pembelajaran PPKn. Pembelajaran PPKn dianggap kurang penting oleh peserta didik sehingga berakibat banyaknya nilai peserta didik yang tidak mencapai KKM pada saat UTS semester 2 mencapai 54 \%. Hasil pengamatan peneliti dikelas X MIA 2 MAN Wonokromo terkait pembelajaran PPKn dapat diketahui bahwa terdapat ketidaksesuaian antara beberapa guru PPKn dalam mengajar

\footnotetext{
${ }^{1}$ Bu nurokhmah selaku guru PPKn kelas X MIA 2 di MAN Wonokromo. Wawancara dilakukan pada tanggal 9 mei 2015 pukul 10.00 WIB
} 
sehingga membingungkan peserta didik. Selain itu hanya $40 \%$ peserta didik yang aktif saat proses pembelajaran berlangsung. Guru masih menggunakan metode ceramah dalam mengajar.

Peneliti juga mewawancarai beberapa peserta $\operatorname{didik}^{2}$, terdapat sebagian peserta didik yang kurang paham pada materi PPKn dan istilah-istilah dalam pelajaran PPKn masih dianggap rumit sehingga hasil belajarnya rendah. Penerapan nilai anti korupsi yang diterapkan kepada peserta didik juga belum maksimal. Dapat diketahui bahwa terdapat permasalahan-permasalahan dalam pembelajaran PPKn antara lain adalah penggunaan model atau metode guru dalam mengajar dan kurangnya penanaman nilai-nilai karakter terutama nilai anti korupsi. Guru masih menerapkan model ceramah ketika mengajar, hal tersebut apabila dilakukan terus menerus akan menimbulkan kejenuhan pada peserta didik sehingga peserta didik kurang aktif dalam proses kegiatan belajar mengajar dan berakibat menurunnya hasil belajar mereka. Selain itu muatan nilai-nilai anti koupsi juga belum tampak baik dalam pembelajaran maupun peserta didik. Berkaitan tentang permasalahan tersebut, diperlukan adanya suatu pembelajaran yang menarik, mudah dipahami, membuat aktif peserta didik dan tidak membosankan yang dapat menumbuhkan interaksi dengan peserta didik lain guna mencapai tujuan pembelajaran. Salah satunya adalah melalui pembelajaran kooperatif. Menurut Slavin (2009: 4) pembelajaran kooperatif merujuk pada berbagai macam metode pengajaran dimana peserta didik bekerja dalam kelompok-kelompok kecil untuk saling membantu satu sama lain dalam mempelajari materi pelajaran. Pembelajaran kooperatif menekankan kerja sama antar peserta didik dalam kelompok untuk mencapai tujuan pembelajarannya. Melalui belajar secara kelompok, peserta didik memperoleh kesempatan untuk saling berinteraksi dengan teman-temannya. Tipe pembelajaran kooperatif ada beberapa macam, salah satunya adalah Student Teams Achievement Division (STAD). Tipe pembelajaran kooperatif ini menuntut para peserta didik untuk aktif dan dapat memahami materi. Keberhasilan model pembelajaran Student Teams Achievement Division dalam meningkatkan keaktifan dan hasil belajar yang dikemukakan oleh Slavin (1978) dapat diketahui bahwa STAD meningkatkan perasaan peserta didik bahwa hasil yang mereka keluarkan tergantung pada kinerja dan bukannya pada keberuntungan. Hasil penelitian Harjono (2009) tentang penerapan model STAD dapat disimpulkan bahwa model pembelajaran ini mampu meningkatkan kualitas pembelajaran kimia yang bermuara pada peningkatan kompetensi peserta didik.

\footnotetext{
${ }^{2}$ Nurhaji, Rahmawati dan Ni'mah pada tanggal 9 mei 2015 dalam hal pembelajaran PPKn di MAN Wonokromo
} 
Berdasarkan penelitian diatas tentang keberhasilan model pembelajaran STAD, maka peneliti akan melakukan penelitian tentang model pembelajaran STAD yang dikolaborasikan dengan nilai-nilai anti korupsi di MAN Wonokromo kelas X MIA 2. Hal tersebut dimaksudkan untuk mengatasi permasalahan-permasalahan pembelajaran PPKn agar sesuai dengan tujuan PPKn khususnya dan tujuan pendidikan pada umumnya. Adapun judul penelitian ini adalah Penerapan model Student Teams Achievement Division berbasis anti korupsi untuk meningkatkan keaktifan dan hasil belajar dalam pembelajaran PPKn kelas X MAN.

\section{Kajian Teori}

Kurang berhasilnya tujuan pembelajaran PPKn salah satunya adalah penerapan model pembelajaran oleh guru yang kurang inovatif. Selain itu penerapan nilai anti korupsi juga belum maksimal. Terkait hal tersebut, peneliti tertarik untuk meneliti tentang penerapan model student teams achievement division berbasis anti korupsi dalam pembelajaran PPKn. Hal tersebut dimaksudkan sebagai salah satu solusi dalam mengatasi permasalahan pembelajaran PPKn. Namun sebelum penelitian lapangan, perlu dikontruksikan terlebih dahulu tentang teoritisnya. Untuk merumuskan asumsi yang kokoh dengan mengkaji hal-hal sebagai berikut:

\section{Student Teams Achievement Division (STAD)}

Pembelajaran kooperatif tipe Student Teams Achievement Division (STAD) yang dikembangkan oleh Robert Slavin dan teman-temannya di Universitas John Hopkin (dalam Slavin;1995) merupakan pembelajaran kooperatif yang paling sederhana, dan merupakan pembelajaran kooperatif yang cocok digunakan oleh guru yang baru mulai menggunakan pembelajaran kooperatif.

Dalam penelitian ini peneliti menggunakan pembelajaran kooperatif model Student Teams Achievement Division karena model ini mudah diterapkan, menarik, dan mudah diadaptasi dalam pembelajaran PPKn, selain itu model STAD sangat tepat diterapkan dalam PPKn karena model STAD memiliki 3 domain pendidikan (kognitif, afektif, dan psikomotor) sehingga dapat meningkatkan keaktifan dan hasil belajar. 


\section{a. Siklus Aktivitas Student Teams Achievement Division (STAD)}

Siklus aktivitas model STAD menurut Sharan (2009:5) sebagai berikut :

1) Peserta didik dibagi menjadi kelompok beranggotakan empat orang yang beragam kemampuan jenis kelamin dan sukunya.

2) Guru memberikan pelajaran.

3) Peserta didik di dalam kelompok itu memastikan bahwa semua anggota kelompok itu bisa menguasai pelajaran tersebut.

4) Semua peserta didik menjalani kuis perseorangan tentang materi tersebut. Mereka tidak dapat membantu satu sama lain.

5) Nilai-nilai hasil kuis peserta didik diperbandingkan dengan nilai rata-rata mereka sendiri sebelumnya.

6) Nilai-nilai diberi hadiah berdasarkan pada seberapa tinggi peningkatan yang bisa mereka capai atau seberapa tinggi nilai itu melampaui nilai mereka yang sebelumnya.

7) Nilai-nilai dijumlahkan untuk mendapatkan nilai kelompok.

8) Kelompok yang bisa mencapai kriteria tertentu bisa mendapatkan sertifikat atau hadiahhadiah lainnya.

\section{b. Komponen Utama STAD}

Ada lima komponen dalam pembelajaran Student Teams Achievement Division yaitu :

1) Presentasi kelas

2) Tim/Tahap Kerja Kelompok.

3) Kuis/Tahap Tes Individu.

4) Tahap perhitungan skor kemajuan individu.

5) Tahap Pemberian Penghargaan / Rekognisi Tim.

\section{c. Langkah-langkah Model STAD}

Sharan (2009:11) menjelaskan bahwa langkah-langkah untuk menggunakan STAD adalah sebagai berikut :

1) Buatlah salinan lembar rekapitulasi kelompok.

2) Merangking peserta didik, dari yang paling pintar ke paling kurang pintar.

3) Tentukan jumlah anggota kelompok, jika memungkinkan tiap-tiap kelompok harus memilih empat anggota. 
4) Masukkan peserta didik dalam kedalam kelompok secara berimbang.

5) Sebarkan lembar rekapitulasi peserta didik.

6) Tentukan nilai dasar.

\section{d. Kelebihan dan kelemahan STAD}

Pembelajaran kooperatif model STAD mempunyai kelebihan dan kekurangan. Menurut Slavin dalam Hartati (1997:21) STAD mempunyai kelebihan sebagai berikut:

1) Dapat mengembangkan prestasi peserta didik, baik hasil tes yang dibuat guru maupun tes baku.

2) Rasa percaya diri peserta didik meningkat, peserta didik merasa lebih terkontrol untuk keberhasilan akademisnya.

3) Strategi kooperatif memberikan perkembangan yang berkesan pada hubungan interpersonal di antara anggota kelompok yang berbeda etnis.

Selain beberapa kelebihan, model STAD juga mempunyai beberapa kekurangan. Menurut Slavin dalam Hartati (1997: 21) cooperative learning model STAD mempunyai kelemahan sebagai berikut:

1) Apabila guru terlena tidak mengingatkan peserta didik agar selalu menggunakan keterampilan-keterampilan kooperatif dalam kelompok maka dinamika kelompok akan tampak macet.

2) Apabila jumlah kelompok tidak diperhatikan, yaitu kurang dari empat, misalnya tiga, maka seorang anggota akan cenderung menarik diri dan kurang aktif saat berdiskusi dan apabila kelompok lebih dari lima maka kemungkinan ada yang tidak mendapatkan tugas sehingga hanya membonceng dalam penyelesaian tugas.

3) Apabila ketua kelompok tidak dapat mengatasi konflik-konflik yang timbul secara konstruktif, maka kerja kelompok akan kurang efektif.

Selain itu Dess (1991) juga menjelaskan kelemahan STAD sebagai berikut:

1) Membutuhkan waktu yang lebih lama untuk peserta didik sehingga sulit mencapai target kurikulum.

2) Membutuhkan waktu yang lebih lama untuk guru sehingga pada umumnya guru tidak mau menggunakan pembelajaran kooperatif.

3) Menuntut sifat tertentu dari peserta didik, misalnya sifat suka bekerja sama. 


\section{Pendidikan Anti Korupsi}

Pendidikan anti korupsi adalah program pendidikan yang diselenggarakan disekolah/madrasah sebagai upaya pencegahan tindak korupsi yang dapat berbentuk penyisipan atau terintregrasi dengan materi mata pelajaran tertentu, di implementasikan dalam bentuk materi kegiatan ekstrakulikuler dan melalui pengembangan budaya di madrasah.

\section{a. Nilai-nilai Anti Korupsi}

Nilai-nilai anti korupsi menurut Kholis (2014 : 23) yaitu sebagaimana dipaparkan dalam tabel 2.3 berikut :

Tabel 2.3 nilai-nilai pendidikan anti korupsi

\begin{tabular}{|c|l|l|}
\hline No & Nilai & Indikator \\
\hline 1. & Jujur & $\begin{array}{l}\text { Selalu berbicara dan berbuat sesuai dengan fakta (konsisten). } \\
\text { Tidak melakukan perbuatan curang. } \\
\text { Tidak berbohong. } \\
\text { Tidak mengakui milik orang lain sebagai miliknya. }\end{array}$ \\
\hline 2. & Disiplin & $\begin{array}{l}\text { Berkomitmen untuk selalu berperilaku konsisten dan } \\
\text { berpegang teguh pada aturan yang ada dalam semua } \\
\text { kegiatan. }\end{array}$ \\
\hline 3. & Tanggung Jawab & $\begin{array}{l}\text { Selalu menyelesaikan pekerjaan atau tugas-tugas secara } \\
\text { tuntas dengan hasil terbaik. }\end{array}$ \\
\hline 4. & Peduli & $\begin{array}{l}\text { Menjaga diri dan lingkungan agar tetap konsisten dengan } \\
\text { aturan yang berlaku. } \\
\text { Selalu berusaha untuk menjadi teladan dalam menegakkan } \\
\text { disiplin, kejujuran, dan tanggung jawab bersama. }\end{array}$ \\
\hline
\end{tabular}

Menurut Komisi Pemberantasan Korupsi (KPK) ada Sembilan nilai-nilai luhur (positif) yang membentuk karakter nilai anti korupsi yaitu jujur, disiplin, tanggung jawab, peduli, kerja keras, berani, mandiri, sederhana dan adil (Kementerian Agama RI; 2014 : 6). Pendapat kedua ahli tersebut dapat disimpulkan bahwa ada Sembilan nilai anti korupsi yaitu jujur, disiplin, tanggung jawab, peduli, kerja keras, berani, mandiri, sederhana dan adil. Dalam penelitian ini hanya menerapkan jujur, disiplin, tanggung jawab, dan peduli, karena mengacu pada modul pendidikan anti korupsi untuk kelas X keluaran KPK.

\section{b. Model Pendidikan Anti Korupsi di Sekolah/Madrasah}

Ada tiga model penyelenggaraan pendidikan untuk menanamkan nilai-nilai anti korupsi yang dapat dilakukan di sekolah/madrasah (Kementerian Agama RI; 2013 : 10) yaitu: 
a) Model Terintegrasi dalam Mata Pelajaran.

b) Model di Luar Pembelajaran melalui Kegiatan Ekstra Kurikuler

c) Model pembudayaan, pembiasaan nilai dalam seluruh aktivitas dan suasana madrasah

\section{Tujuan Pendidikan Anti Korupsi}

Pendidikan anti korupsi bertujuan untuk menanamkan nilai dan sikap hidup anti korupsi yang diimplementasikan dikehidupan sehari-hari sehingga dapat mencegah tindakan korupsi sekarang dan dikemudian hari. Adanya pendidikan korupsi menjadikan peserta didik mempunyai sikap untuk memerangi tindakan korupsi.

\section{Metode}

Jenis penelitian ini menggunakan Penelitian Tindakan Kelas (PTK) yang dilaksanakan dengan bekerja sama dengan guru mata pelajaran PPKn kelas X MIA 2 MAN Wonokromo. Dalam hal ini peneliti sebagai pelaksana yang terlibat langsung dalam merencanakan tindakan, observasi, refleksi, dan lain-lain. Penelitian ini dilaksanakan pada semester 2 kurang lebih lima bulan, yaitu sejak bulan maret sampai bulan Juli 2012 dan dilakukan dalam 2 siklus. Subjek penelitian ini adalah :

1. Kelas X MIA 2 MAN Wonokromo yang berjumlah 32 peserta didik yang terdiri dari 14 laki-laki dan 18 perempuan sebagai penerima tindakan.

2. Guru mata pelajaran PPKn selaku kolaborator.

3. Kepala sekolah membantu memberikan ijin penelitian.

4. Peneliti bertugas merencanakan, mengumpulkan data, menganalisis data dan membuat kesimpulan penelitian.

\section{Kriteria Keberhasilan}

1. Meningkatnya keaktifan peserta didik saat proses pembelajaran berlangsung yang diamati menggunakan lembar observasi keaktifan peserta didik.

2. Peningkatan hasil belajar peserta didik yang ditunjukkan dengan kenaikan rata-rata tes pada setiap siklus dan nilai mencapai KKM sebesar > 72 atau ekuivalen 2.85. 
3. Peningkatan hasil belajar peserta didik yang ditunjukkan dengan kenaikan nilai rata-rata kelas lebih besar dari KKM yakni > 72 atau ekuivalen 2.85 .

Hasil dan pembahasan

Berikut disajikan data dan setiap siklus dan pembahasannya

Siklus 1

Sebelum peneliti melakukan tindakan, peneliti melakukan observasi dan wawancara awal untuk mengetahui kondisi awal kelas. Hasil wawancara awal dan observasi sebelum melakukan tindakan akan dijelaskan berikut ini :

a. Penerapan nilai-nilai anti korupsi oleh guru PPKn kelas X MIA 2.

Sebagaimana telah dijelaskan dalam bab sebelumnya, hasil wawancara peneliti dengan guru PPKn kelas X MIA 2 bahwa penerapan pendidikan anti korupsi oleh guru PPKn hanya meliputi nilai jujur dan percaya diri saat pembelajaran sedang berlangsung. Peneliti juga melihat peserta didik kurang bertanggung jawab dan peduli saat pembelajaran sedang berlangsung. Hal ini bisa dilihat saat guru sedang menerangkan ada peserta didik yang berbicara sendiri, melamun dan bermain HP.

b. Keaktifan dan Hasil Belajar Peserta Didik.

Dari hasil observasi, peneliti melihat hanya beberapa peserta didik yang aktif. Jika di persentasekan sebesar $40 \%$ dan hanya terlihat beberapa peserta didik yang bertanya dan berpendapat. Untuk hasil belajar bisa di lihat saat Ujian Tengah Semester (UTS) semester 2 hanya 54\% peserta didik yang memenuhi KKM. Dari hasil wawancara dan observasi di peroleh informasi adanya permasalahan dalam pembelajaran PPKn yaitu peserta didik yang kurang aktif dan kurang maksimalnya hasil belajar peserta didik. Dari permasalahan tersebut dapat diidentifikasikan faktor penyebab masalah yaitu pembelajaran dianggap kurang penting oleh peserta didik sehingga berakibat banyaknya nilai peserta didik yang tidak memenuhi KKM pada saat UTS semester 2, terdapat ketidaksesuaian antara beberapa guru PPKn dalam mengajar sehingga membingungkan peserta didik, terdapat sebagian peserta didik yang kurang paham pada materi PPKn dan istilah-istilah dalam pelajaran PPKn masih dianggap rumit sehingga hasil belajarnya rendah, dan penerapan nilai anti korupsi yang diterapkan kepada peserta didik juga belum maksimal. Jika di persentasekan hanya $40 \%$ peserta didik yang aktif saat proses pembelajaran berlangsung dan peserta didik yang tidak mencapai KKM pada saat UTS semester 
2 mencapai 54\%. Identifikasi faktor penyebab permasalahan dalam pembelajaran PPKn kelas X MIA 2 dapat di asumsikan penyebab permasalahan tersebut antara lain penggunaan model atau metode guru dalam mengajar dan penanaman nilai-nilai karakter terutama nilai anti korupsi. Guru masih banyak menerapkan model ceramah ketika mengajar, hal tersebut apabila dilakukan terus menerus akan menimbulkan kejenuhan pada peserta didik sehingga peserta didik kurang aktif dalam proses kegiatan belajar mengajar dan berakibat menurunnya hasil belajar mereka. Selain itu muatan nilai-nilai anti koupsi juga belum tampak baik dalam pembelajaran maupun peserta didik.

Mengatasi permasalahan tersebut diperlukan adanya suatu pembelajaran yang menarik, mudah dipahami, membuat aktif peserta didik, tidak membosankan yang dapat menumbuhkan interaksi dengan peserta didik lain guna mencapai tujuan pembelajaran dan penerapan nilai anti korupsi yang di integrasikan dalam pembelajaran PPKn. Salah satunya adalah melalui penerapan Student Teams Achievement Division berbasis anti korupsi.

Data tentang hasil tes dan hasil observasi keaktifan peserta didik siklus 1 dapat disajikan pada table berikut :

Tabel 4.8 Rekapitulasi observasi keaktifan siklus 1

\begin{tabular}{|c|c|c|c|c|c|c|}
\hline \multirow{2}{*}{ No } & \multirow{2}{*}{ Indikator aktivitas } & \multicolumn{4}{|c|}{ Banyak Nilai } & \multirow{2}{*}{ Jumlah } \\
\hline & & 1 & 2 & 3 & 4 & \\
\hline 1. & Mendengarkan penjelasan guru & & & 3 & 21 & 24 \\
\hline 2. & Menjawab pertanyaan guru & & & 4 & 20 & 24 \\
\hline 3. & $\begin{array}{l}\text { Peserta didik bertanya dan } \\
\text { berpendapat }\end{array}$ & & 6 & 7 & 11 & 24 \\
\hline 4. & Aktif ketika diskusi kelompok & & & 9 & 15 & 24 \\
\hline 5. & $\begin{array}{l}\text { Mempresentasikan hasil tugas } \\
\text { kelompok }\end{array}$ & 16 & & & 8 & 24 \\
\hline 6. & Tidak mengganggu teman & & 4 & 10 & 10 & 24 \\
\hline 7. & Tidak melamun & & & 17 & 7 & 24 \\
\hline 8. & $\begin{array}{l}\text { Berpegang teguh pada aturan yang } \\
\text { ada dalam semua kegiatan }\end{array}$ & & & & 24 & 24 \\
\hline 9. & Menyelesaikan tugas dengan baik & & & 2 & 22 & 24 \\
\hline 10 & $\begin{array}{l}\text { Membantu teman jika mengalami } \\
\text { kesulitan }\end{array}$ & & 1 & 2 & 21 & 24 \\
\hline & Jumlah & 16 & 11 & 54 & 159 & 240 \\
\hline & Persentase & $\begin{array}{l}6.7 \\
\%\end{array}$ & $4.6 \%$ & $22.5 \%$ & $66.25 \%$ & $100 \%$ \\
\hline & Persentase keaktifan kelas & & & & & $86.25 \%$ \\
\hline
\end{tabular}


Berdasarkan dari hasil rekapitulasi data diatas, menunjukkan urutan dari yang terbanyak adalah yang mendapat nilai 4 sebanyak 159 poin atau $66.25 \%$, nilai 3 sebanyak 54 poin atau 22.5\%, nilai 1 sebanyak 16 poin atau $6.7 \%$ dan nilai 2 sebanyak 11 poin 4.6\%. dapat disimpulkan bahwa persentase keaktifan kelas adalah $86.25 \%$ menunjukkan bahwa peserta didik sangat aktif.

1) Hasil belajar peserta didik pada siklus 1

Tabel 4.9 Data hasil belajar ( pre test dan post test )

\begin{tabular}{|c|c|c|c|}
\hline No & Nama & Pre test & Post test \\
\hline 1. & Adi Arfani Abdul M. & $\mathrm{S}$ & $\mathrm{S}$ \\
\hline 2. & Agus Ahmad Fauzi & 80 & 80 \\
\hline 3. & Ahmad AliWafa & 80 & 90 \\
\hline 4. & Angling Yusuf Sa'bana & 60 & 90 \\
\hline 5. & Anik Tri W. & 80 & 80 \\
\hline 6 & Anikmatul Hikmah & 80 & 80 \\
\hline 7 & Ari Safitri Rahmawati & 50 & 90 \\
\hline 8 & Aurely Mumtaza & 60 & 80 \\
\hline 9 & Dian Putra Mahardika & $\mathrm{S}$ & $\mathrm{S}$ \\
\hline 10 & Ervi Yanti & 90 & 90 \\
\hline 11 & Faizatul Fauziah & $\mathrm{S}$ & $\mathrm{S}$ \\
\hline 12 & Febrian Daris Wardana & 50 & 70 \\
\hline 13 & Ferry Fitrianto & 80 & 80 \\
\hline 14 & Halimatus Sa'diyah & 80 & 80 \\
\hline 15 & Ida Safitri & 60 & 80 \\
\hline 16 & Ika Nur Zulaifah & 80 & 90 \\
\hline 17 & Ilkham Wibowo P. & I & I \\
\hline 18 & Iqlides Ahmad Miyaqi & I & I \\
\hline 19 & Muhamad Maulana S. & $\mathrm{S}$ & $\mathrm{S}$ \\
\hline 20 & M. Sahid Bayu Aji & 60 & 80 \\
\hline 21 & Mustafidatul Ni'mah & $\mathrm{S}$ & $\mathrm{S}$ \\
\hline 22 & Nur Hidayati & 70 & 80 \\
\hline
\end{tabular}




\begin{tabular}{|l|l|l|l|}
\hline 23 & Nur Marsudah & 60 & 80 \\
\hline 24 & Nurul Fauziah & 60 & 70 \\
\hline 25 & Reka Nuraini & 80 & 90 \\
\hline 26 & Rizal Kurniawan & 60 & 80 \\
\hline 27 & Rizki Rahmawati & 70 & 100 \\
\hline 28 & Sabtian Nurhaji Asidiq & I & I \\
\hline 29 & Tania Ariani & 60 & 80 \\
\hline 30 & Tsania Mubarok & 60 & 80 \\
\hline 31 & Vina Idamatus Silmi & 80 & 90 \\
\hline 32 & Wiwid Idayanti & 80 & 90 \\
\hline & JUMLAH & $\mathbf{1 6 7 0}$ & $\mathbf{2 0 0 0}$ \\
\hline & RATA-RATA & $\mathbf{6 9}$ & $\mathbf{8 3 . 3}$ \\
\hline & TUNTAS & $\mathbf{1 1}$ & $\mathbf{2 2}$ \\
\hline & TIDAK TUNTAS & $\mathbf{1 3}$ & $\mathbf{2}$ \\
\hline
\end{tabular}

Dari hasil belajar pada tabel diatas dapat diketahu nilai rata-rata kelas pada post test siklus 1 yaitu 83.3, ada 2 peserta didik yang belum memenuhi KKM pada post test siklus 1 sedangkan nilai rata-rata kelas pada pre test yaitu 69 . Adanya peningkatan nilai rata-rata kelas dari nilai pre test sampai dengan post test siklus pertama sebanyak 14.3 . Rata-rata peserta didik mengalami peningkatan skor kemajuan individu dari pre test ke post test sebesar 20 poin.

\section{a. Tahap refleksi}

Pada tahap ini peneliti dan kolaborator mengadakan pertemuan. Kolaborator/pengamat menyampaikan hal-hal yang ditemukan selama tindakan. Peneliti mencatat sebagai masukan untuk bahan perbaikan pada tindakan berikutnya.

Dalam pelaksanaan kegiatan pembelajaran diperoleh informasi dari pengamatan sebagai berikut :

1) Saat mengerjakan pre test Muhammad sahid melihat laptop.

2) Saat peneliti menyampaikan materi agus ahmad aliwafa malah menggambar.

3) Persiapan pembentukan kelompok harus diplaning sejak awal .

4) Soal analisis kasus lebih baik diberikan berupa print out jangan melalui LCD.

5) Saat diskusi Ferry kurang terlibat. 
Siklus 2

Peneliti melakukan persiapan dengan memperbaiki kekurangan pada siklus 1 dan menyusun instrument penelitian yang terdiri dari post test, materi pembelajaran, lembar kerja berupa analisis kasus, serta lembar observasi. Jam pelajaran pada siklus kedua di undur menjadi pukul 11.00 WIB karena paginya ada acara peringatan hari tembakau.

Tabel 4.11 Rekapitulasi observasi keaktifan siklus 2

\begin{tabular}{|c|c|c|c|c|c|c|}
\hline \multirow{2}{*}{ No } & \multirow{2}{*}{ Indikator aktivitas } & \multicolumn{4}{|c|}{ Banyak Nilai } & \multirow{2}{*}{ Jumlah } \\
\hline & & 1 & 2 & 3 & 4 & \\
\hline 1. & Mendengarkan penjelasan guru & & & 2 & 27 & 29 \\
\hline 2. & Menjawab pertanyaan guru & & & 6 & 23 & 29 \\
\hline 3. & $\begin{array}{l}\text { Peserta didik bertanya dan } \\
\text { berpendapat }\end{array}$ & & & 14 & 15 & 29 \\
\hline 4. & Aktif ketika diskusi kelompok & & 2 & 10 & 17 & 29 \\
\hline 5. & $\begin{array}{l}\text { Mempresentasikan hasil tugas } \\
\text { kelompok }\end{array}$ & 8 & & & 21 & 29 \\
\hline 6. & Tidak mengganggu teman & & & 10 & 19 & 29 \\
\hline 7. & Tidak melamun & & 1 & 12 & 16 & 29 \\
\hline 8. & $\begin{array}{l}\text { Berpegang teguh pada aturan } \\
\text { yang ada dalam semua } \\
\text { kegiatan }\end{array}$ & & & 3 & 26 & 29 \\
\hline 9. & $\begin{array}{l}\text { Menyelesaikan tugas dengan } \\
\text { baik }\end{array}$ & & & 1 & 28 & 29 \\
\hline \multirow[t]{4}{*}{10} & $\begin{array}{l}\text { Membantu teman jika } \\
\text { mengalami kesulitan }\end{array}$ & & & 2 & 27 & 29 \\
\hline & Jumlah & 8 & 3 & 60 & 219 & 290 \\
\hline & Persentase & $2.75 \%$ & $1.03 \%$ & $20.6 \%$ & $75.5 \%$ & $100 \%$ \\
\hline & Persentase keaktifan kelas & & & & & $91.75 \%$ \\
\hline
\end{tabular}

Berdasarkan dari hasil rekapitulasi data diatas, menunjukkan urutan dari yang terbanyak adalah yang mendapat nilai 4 sebanyak 219 poin atau $75.5 \%$, nilai 3 sebanyak 60 poin atau 20.6\%, nilai 1 sebanyak 8 poin atau $2.75 \%$ dan nilai 2 sebanyak 3 poin 1.03\%. Dapat disimpulkan bahwa persentase keaktifan secara keseluruhan adalah 91.75\% menunjukkan bahwa peserta didik sangat aktif. 
1) Hasil belajar peserta didik pada siklus 2

Tabel 4.12 Data hasil belajar ( post test )

\begin{tabular}{|c|c|c|}
\hline No & Nama & Post test \\
\hline 1. & Adi Arfani Abdul M. & 80 \\
\hline 2. & Agus Ahmad Fauzi & 85 \\
\hline 3. & Ahmad AliWafa & $\mathrm{S}$ \\
\hline 4. & Angling Yusuf Sa'bana & 80 \\
\hline 5. & Anik Tri W. & 90 \\
\hline 6 & Anikmatul Hikmah & 95 \\
\hline 7 & Ari Safitri Rahmawati & 95 \\
\hline 8 & Aurely Mumtaza & 90 \\
\hline 9 & Dian Putra Mahardika & 80 \\
\hline 10 & Ervi Yanti & 90 \\
\hline 11 & Faizatul Fauziah & 80 \\
\hline 12 & Febrian Daris Wardana & 85 \\
\hline 13 & Ferry Fitrianto & 90 \\
\hline 14 & Halimatus Sa'diyah & 90 \\
\hline 15 & Ida Safitri & 90 \\
\hline 16 & Ika Nur Zulaifah & 95 \\
\hline 17 & Ilkham Wibowo P. & I \\
\hline 18 & Iqlides Ahmad Miyaqi & I \\
\hline 19 & Muhamad Maulana S. & 80 \\
\hline 20 & M. Sahid Bayu Aji & 95 \\
\hline 21 & Mustafidatul Ni'mah & 80 \\
\hline 22 & Nur Hidayati & 95 \\
\hline 23 & Nur Marsudah & 95 \\
\hline 24 & Nurul Fauziah & 80 \\
\hline 25 & Reka Nuraini & 80 \\
\hline 26 & Rizal Kurniawan & 80 \\
\hline
\end{tabular}




\begin{tabular}{|l|l|l|}
\hline 27 & Rizki Rahmawati & 100 \\
\hline 28 & Sabtian Nurhaji Asidiq & 90 \\
\hline 29 & Tania Ariani & 80 \\
\hline 30 & Tsania Mubarok & 80 \\
\hline 31 & Vina Idamatus Silmi & 90 \\
\hline 32 & Wiwid Idayanti & 90 \\
\hline & JUMLAH & $\mathbf{2 5 3 0}$ \\
\hline & RATA-RATA & $\mathbf{8 7 . 2 4}$ \\
\hline & TUNTAS & $\mathbf{2 9}$ \\
\hline & TIDAK TUNTAS & $\mathbf{0}$ \\
\hline
\end{tabular}

Dari hasil belajar pada tabel diatas dapat diketahu nilai rata-rata kelas pada post test siklus 2 yaitu 87.24, semua peserta didik memenuhi KKM pada post test siklus 2. Adanya peningkatan nilai rata-rata kelas dari nilai post test siklus 1 sampai dengan post test siklus 2 sebanyak 3.94. Rata-rata kemajuan skor setiap peserta didik sebesar 20 sampai 30 poin.

\section{Tahap refleksi}

Pada tahap ini peneliti melakukan refleksi untuk siklus 2. Dalam pelaksanaan kegiatan pembelajaran diperoleh informasi dari pengamatan sebagai berikut :

1. Seluruh peserta didik sudah aktif dan adanya peningkatan keaktifan dari siklus 1 sampai dengan siklus 2 .

2. Hasil post test siklus 2 mengalami peningkatan.

3. Setelah di analisis didapatkan kesimpulan bahwa hasil dari siklus kedua sudah memenuhi kriteria keberhasilan penelitian dan sudah dianggap cukup dan berhasil.

\section{Pembahasan Hasil Penelitian.}

1. Dari data yang diperoleh, menunjukkan bahwa pembelajaran PPKn dengan menggunakan model Student Teams Achievement Division berbasis anti korupsi meningkatkan aktivitas dan hasil belajar peserta didik. Hal ini dapat dilihat dari perubahan skor yang diperoleh dari siklus ke siklus mengalami peningkatan. 
2. Penerapan pendidikan anti korupsi yang diintegrasikan dengan pembelajaran PPKn mewujudkan peserta didik lebih jujur, disiplin, bertanggungjawab dan perduli. Hal ini dapat dilihat dari meningkatnya sikap keperdulian, rasa tanggungjawab, dan disiplin peserta didik saat proses pembelajaran berlangsung dan hasil observasi. Nilai kejujuran bisa dilihat dari peserta didik saat mengerjakan tugas dan tes individu.

3. Dari hasil wawancara dengan guru PPKn, penerapan nilai anti korupsi saat pembelajaran. Peserta didik diminta untuk selalu percaya diri dan menekankan kejujuran. Penerapan nilai anti korupsi di lingkungan madrasah bisa di lihat dengan adanya kantin kejujuran yang secara tidak langsung melatih dan membiasakan peserta didik untuk selalu jujur.

4. Proses pembelajaran didasarkan pada pencarian dan penemuan melalui proses berpikir secara sistematis.

5. Proses pembelajaran dirancang agar peserta didik lebih aktif. Salah satu indikator peserta didik itu aktif ketika peserta didik bertanya dan menjawab. Bertanya dapat dipandang sebagai refleksi dari keingintauan setiap individu, sedangkan menjawab pertanyaan mencerminkan kemampuan seseorang dalam berpikir. Dalam proses pembelajaran dengan model STAD, peneliti tidak menyampaikan informasi begitu saja akan tetapi memancing agar peserta didik dapat menemukan sendiri. Oleh sebab itu bertanya sangat penting, sebab melalui pertanyaan-pertanyaan, peneliti dapat membimbing dan mengarahkan peserta didik untuk menemukan setiap materi PPKn yang dipelajari.

Dari hasil observasi keaktifan keseluruhan menunjukkan bahwa model student teams achievement division dapat meningkatkan aktivitas belajar peserta didik. Peningkatan aktivitas dapat dilihat dari hasil observasi keseluruhan pada siklus 1 dan siklus 2, dan terlihat peserta didik sangat aktif. Partisipasi peserta didik meningkat, hal ini dibuktikan adanya partisipasi peserta didik dalam indikator mendengarkan penjelasan guru mengalami peningkatan dari siklus 1 sampai dengan siklus 2. Hal ini disebabkan karena peserta didik menyadari pentingnya materi pembelajaran yang disampaikan peneliti sehingga menyebabkan rasa ingin tahu peserta didik lebih besar dan pembelajaran yang disampaikan peneliti menarik. Wujud partisipasi peserta didik pada indikator menjawab pertanyaan guru mengalami peningkatan. Hal ini di buktikan dengan banyaknya peserta didik yang menjawab pertanyaan saat proses pembelajaran sedang berlangsung pada siklus 1 dan siklus 2 , dan saat penyimpulan materi. 
Partisipasi peserta didik saat bertanya dan berpendapat selalu mengalami peningkatan dari siklus 1 sampai dengan siklus 2. Banyak peserta didik yang bertanya saat peneliti menyampaikan materi, ketika ada temannya yang sedang presentasi didepan kelas dan ketika peneliti menayangkan foto yang berkaitan dengan materi. Begitu pula banyak peserta didik yang berpendapat ketika peneliti menyampaikan kembali analisis kasus yang sedang dibahas dan ketika menyampaikan pendapat atas jawaban kelompok lain yang sedang presentasi.

Peserta didik juga aktif ketika diskusi kelompok, hal ini di buktikan dengan peningkatan dari siklus 1 sampai dengan siklus 2 dan jawaban yang bervariatif ketika mereka menganalisis sebuah kasus. Peserta didik saling bertukar informasi dan berpendapat ketika menganalis sebuah kasus dengan kelompoknya. Pada indikator mempresentasikan hasil tugas kelompok mengalami peningkatan dari siklus 1 sampai dengan siklus 2. Hal ini terbukti banyak peserta didik yang berebut ingin presentasi di depan kelas dan peserta didik antusias ketika mereka mempresentasikan hasil tugas kelompoknya.

Peserta didik antusias dengan pembelajaran yang sedang berlangsung. Peserta didik juga fokus dengan materi yang disampaikan oleh peneliti, peserta didik pun tidak mengganggu temannya dan tidak melamun ketika pembelajaran sedang berlangsung. Hal ini bisa di buktikan dengan banyaknya peserta didik yang menjawab pertanyaan, berpendapat dan bertanya. Peserta didik berpegang teguh pada aturan yang ada dalam semua kegiatan. Ketika peserta didik mengerjakan pre test dan post test peserta didik tidak boleh saling membantu dan mencontek. Peserta didik pun patuh ketika peneliti membuat peraturan yaitu jika mereka ingin bertanya kepada kelompok lain yang sedang presentasi maka pertanyaannya tidak boleh menjatuhkan kelompok yang di depan, pertanyaannya tidak boleh melenceng dari topik, dan pertanyaan harus berbobot. Semua peserta didik menyelesaikan tugas dengan baik. Hal tersebut di buktikan dengan jawaban analisis kasus yang bervariatif. Selain itu mereka sangat aktif ketika diskusi kelompok dan peserta didik pun saling membantu ketika salah satu temannya mengalami kesulitan. Uraian diatas dapat disimpulkan bahwa terdapat 3 domain pendidikan dalam pembelajaran model STAD yaitu bisa dilihat pada aspek kognitif seperti peserta didik mampu mengingat materi sebelumnya, peserta didik mampu menganalisis sebuah kasus, peserta didik lebih memahami isi materi yang sedang dibahas, meningkatkan kemampuan memandang masalah dan situasi dari berbagai perspektif dan meningkatkan hasil belajar. Pada aspek afektif 
bisa dilihat dari peningkatan rasa percaya diri peserta didik terlihat ketika mereka berebut maju kedepan untuk presentasi, peserta didik ketika bertanya dan berpendapat, mendengarkan penjelasan guru, menjawab pertanyaan guru, tidak mengganggu teman dan tidak melamun. Aspek psikomotorik ini bisa dilihat dari pengembangan keterampilan sosial dan komitmen seperti mereka mengungkapkan pendapat dari sebuah kasus yang diangkat dan kesediaan menggunakan ide orang lain yang dirasa lebih baik.

Penerapan nilai anti korupsi bisa dilihat dari aspek ketika peserta didik berpegang teguh pada aturan yang ada dalam semua kegiatan dan tidak melamun ketika pembelajaran sedang berlangsung, hal itu mencerminkan nilai disiplin, sedangkan nilai tanggung jawab terdapat dalam aspek peserta didik menyelesaikan tugas dengan baik, mendengarkan penjelasan guru dan mereka patuh dengan peraturan yang peneliti buat. Sikap peserta didik yang membantu temannya yang mengalami kesulitan dan tidak mengganggu temannya mencerminkan nilai peduli. Nilai jujur bisa dilihat saat peserta didik mengerjakan pre test dan post test.

Dari hasil penelitian dan pembahasan diatas dapat disimpulkan bahwa model Student Teams Achievement Division dapat meningkatkan keaktifan dan hasil belajar peserta didik. Pengertian dari STAD adalah tipe pembelajaran kooperatif yang menekankan pada aktivitas dan interaksi antara peserta didik untuk saling memotivasi dan saling membantu dalam menguasai materi pelajaran guna mencapai prestasi yang maksimal.

Suasana pembelajaran di dalam kelas, aktivitas peserta didik secara individu maupun kelompok, mempresentasikan hasil, dan lain sebagainya terlihat hidup, menyenangkan dan selalu mengalami peningkatan. Penerapan nilai-anti korupsi juga terlihat dari beberapa indikator keaktifan peserta didik dan ketika peserta didik mengerjakan pre test dan post tes

\section{Kesimpulan}

Dari rangkaian siklus penelitian tindakan kelas yang telah dilakukan terlihat adanya perubahan yang merupakan hasil penelitian dalam rangka usaha meningkatkan keaktifan dan hasil belajar peserta didik kelas X MIA 2 MAN Wonokromo. Bertolak dari tindakan penelitian yang telah di lakukan, maka dapat disimpulkan sebagai berikut :

1. Penerapan pendidikan anti korupsi oleh guru PPKn saat pembelajaran, peserta didik diminta untuk selalu percaya diri dan selalu menekankan kejujuran dalam setiap pembelajaran. 
Penerapan nilai anti korupsi di lingkungan madrsah salah satu contohnya dengan adanya kantin kejujuran yang secara tidak langsung melatih dan membiasakan kejujuran peserta didik.

2. Penerapan model Student Teams Achievement Division berbasis anti korupsi untuk meningkatkan keaktifan dan hasil belajar dalam pembelajaran PPKn kelas X MIA 2 MAN Wonokromo tahun pelajaran 2014/2015 khususnya materi kesadaran berbangsa dan bernegara sebagai berikut :

a. Penerapan model STAD dalam pembelajaran PPKn terlihat adanya 3 domain pendidikan yaitu pada aspek kognitif seperti peserta didik mampu mengingat materi sebelumnya, peserta didik mampu menganalisis sebuah kasus, peserta didik lebih memahami isi materi yang sedang dibahas, meningkatkan kemampuan memandang masalah dan situasi dari berbagai perspektif dan meningkatkan hasil belajar. Pada aspek afektif bisa dilihat dari peningkatan rasa percaya diri peserta didik terlihat ketika mereka berebut maju kedepan untuk presentasi, peserta didik ketika bertanya dan berpendapat, mendengarkan penjelasan guru, menjawab pertanyaan guru, tidak mengganggu teman dan tidak melamun. Aspek psikomotorik ini bisa dilihat dari pengembangan keterampilan sosial dan komitmen seperti mereka mengungkapkan pendapat dari sebuah kasus yang diangkat dan kesediaan menggunakan ide orang lain yang dirasa lebih baik.

b. Dalam setiap siklus peneliti menerapkan nilai-nilai anti korupsi seperti jujur, disiplin, tanggung jawab, dan peduli. Penerapan nilai anti korupsi bisa dilihat dari aspek ketika peserta didik berpegang teguh pada aturan yang ada dalam semua kegiatan dan tidak melamun ketika pembelajaran sedang berlangsung, hal itu mencerminkan nilai disiplin, sedangkan nilai tanggung jawab terdapat dalam aspek peserta didik menyelesaikan tugas dengan baik, mendengarkan penjelasan guru dan mereka patuh dengan peraturan yang peneliti buat. Sikap peserta didik yang membantu temannya yang mengalami kesulitan dan tidak mengganggu temannya mencerminkan nilai peduli. Nilai jujur bisa dilihat saat peserta didik mengerjakan pre test dan post test.

3. Persentase keberhasilan penerapan model Student Teams Achievement Division berbasis anti korupsi untuk meningkatkan keaktifan dan hasil belajar dalam pembelajaran PPKn kelas X MIA 2 MAN Wonokromo yaitu bisa dilihat dari persentase keaktifan pada siklus 1 yaitu 
sebesar $86.25 \%$ dan pada siklus 2 sebesar 91.75\% menandakan bahwa penerapan Student Teams Achievement Division berbasis anti korupsi menjadikan peserta didik sangat aktif. Sedangkan persentase untuk keberhasilan hasil belajar peserta didik yaitu sebelum tindakan diadakan pre test terlebih dahulu. Hasil pre test sebesar 69 dengan persentase ketuntasan 45\%. Hasil post test siklus 1 sebesar 83.3 dengan persentase ketuntasan $91.6 \%$ dan hasil post test siklus 2 sebesar 87.24 dengan persentase ketuntasan 100\%. Dilihat dari hasil diatas persentase keaktifan dan hasil belajar meningkat pada setiap siklus.

\section{Implikasi}

Hasil kegiatan pembelajaran yang telah di lakukan selama 2 siklus dan berdasarkan pembahasan serta analisis yang telah dilakukan dapat disimpulkan bahwa penerapan model Student Teams Achievement Division berbasis anti korupsi dapat meningkatkan keaktifan dan hasil belajar dalam pembelajaran PPKn kelas X MIA 2 MAN Wonokromo.

\section{Saran}

Berdasarkan hasil penelitian, agar proses pembelajaran PPKn menarik, inovatif, mudah dipahami membuat peserta didik aktif, serta menjadikan moral dan karakter peserta didik lebih baik maka disimpulkan saran sebagai berikut :

1. Saran bagi Kepala Sekolah.

Perlu adanya penanaman nilai anti korupsi melalui pembudayaan seluruh Pembudayaan akan menimbulkan suatu pembiasaan. Untuk menumbuhkan budaya anti korupsi sekolah/madrasah perlu merencanakan suatu budaya dan kegiatan pembiasaan. Pembiasaan adalah alat pendidikan. Bagi peserta didik yang masih kecil, pembiasaan sangat penting. Karena dengan pembiasaan itulah akhirnya suatu aktivitas akan menjadi milik peserta didik di kemudian hari. Pembiasaan yang baik akan membentuk sosok manusia yang berkepribadian yang baik pula.

2. Saran bagi guru PPKn.

a. Penerapan pembelajaran PPKn harus professional. Proses pembelajaran PPKn harus dikolaborasikan langsung dengan nilai-nilai anti korupsi.

b. diperlukan adanya suatu pembelajaran yang menarik, mudah dipahami, membuat aktif peserta didik dan tidak membosankan yang dapat menumbuhkan interaksi dengan peserta 
didik lain guna mencapai tujuan pembelajaran. Salah satunya adalah melalui pembelajaran kooperatif tipe STAD.

c. Penerapan pembelajaran PPKn yang professional dan kompeten akan mewujudkan peserta didik yang berkualitas baik dalam disiplin sosial, etos kerja, dalam produktivitas kerja, kemampuan intelektual, tanggung jawab kemasyarakatan, kebangsaan, kemanusiaan, bermoral, berkarakter dan berkepribadian.

3. Saran bagi peserta didik.

a. Perlu adanya kesadaran peserta didik bahwa pembelajaran PPKn itu penting, sehingga dengan kesadaran peserta didik akan pentingnya pembelajaran PPKn maka akan meningkatkan keaktifan peserta didik.

b. Perlu banyak membaca agar dalam memahami istilah-istilah dalam pembelajaran PPKn bisa lebih mengerti sehingga hasil belajar akan meningkat.

c. Penerapan nilai anti korupsi yang diterapkan oleh peneliti bisa menjadi suatu pembiasaan dalam kehidupan kesehariannya sehingga peserta didik bisa menjadi manusia yang berakhlak mulia dan menambahkan kesadaran berbangsa dan bernegara, yang kelak tidak melakukan tindakan korupsi.

\section{Daftar Pustaka}

Arikunto, S. (2010). “Dasar-Dasar Evaluasi Pendidikan (Edisi Revisi)”. Jakarta: Bumi Aksara.

Dess, Robert L. (1991). "The Role of Cooperative Learning in Increasing Problem Solving Ability in a Collage Remedial Course". Journal for Research in Mathematics Education.

Dimyati dan Mudjiono. (2006). “Belajar dan Pembelajaran”. Jakarta : Rineka Cipta.

Harjono. (2010). "Meningkatkan Kompetensi Siswa dalam Pembelajaran Kimia Melalui Pembelajaran Kooperatif STAD”. Jurnal Penelitian Pendidikan: Volume 27 nomor 1 tahun 2010.

Harmoko. (2013). "Penerapan pembelajaran kooperatif model student teams-achievement divisions (STAD) ditinjau dari Kekatifan Siswa dan Hasil Belajar Siswa Mata Pelajaran Menggunakan Alat Ukur Kelas X Jurusan Teknik Pemesinan di SMK Muhammadiyah Prambanan”. Yogyakarta : UNY.

Isjoni. (2009). “Cooperative Learning Efektivitas Pembelajaran Kelompok”. Bandung : Alfabeta. 
Kementerian Agama RI Direktorat Jendral Pendidikan Islam. (2013). “ Panduan Penyelenggaraan Pendidikan Anti Korupsi di Madrasah”. Jakarta : Kementerian Agama RI Direktorat Jendral Pendidikan Islam.

Mehrens, W.A, dan I.J. Lehman. (1978). "Measurment and Evaluation in Education and Psychology second edition". New York : Holt Rinehart and Winston.

Miles, Matthew B. dan Michael Huberman. (1992). "Analisis Data Kualitatif (Buku Sumber Tentang Metode-Metode Baru)". Jakarta :UIP

Moloeng, lexy J. (2004). “Metode Penelitian Kualitatif”. Bandung : PT. Remaja Rosda Karya.

Muhibbin, Syah. (1999). “Psikologi Pendidikan dengan Pendekatan Baru”. Bandung : PT. Remaja Rosda Karya.

Purwodarminto. (2005). “Kamus Besar Bahasa Indonesia Edisi Ketiga”. Jakarta : Depdiknas.

Rochman Natawidjaya dan H.A. Moein Moesa. (1992). "Psikologi Pendidikan". Jakarta : Depdikbud Dirjen Dikti.

Pohan, Rusdin. (2007). “Metodologi Penelitian Pendidikan”. Yogyakarta : Ar Rijal Institute.

Sharan, S. (2009). "Handbook of Cooperative Learning Inovasi Pengajaran dan Pembelajaran untuk Memacu Keberhasilan Siswa di Kelas". Diterjemahkan oleh Sigit Prawoto. Yogyakarta : Imperium.

Slavin, Robert. E. (2008). “Cooperative Learning, Teori, Riset dan Praktek”. Diterjemahkan oleh Narulita Yusron. Bandung : Nusa Media.

Sudrajat, Akhmad. (2008). "Cooperative Learning Teknik Jingsaw”. Jakarta : Persada.

Sulistiyah. Endang, dkk. (2011). “ Meningkatkan Keaktifan dan Keterampilan Siswa Pemecahan Masalah dalam Pembelajaran Matematika dengan Penerapan Model Student Teams Achievement Division (STAD)". Jurnal Penelitian Tindakan Kelas :volume khusus nomor 1 tahun 2011. 